\title{
Role of phospholipase D1 in glucose-induced insulin secretion in pancreatic $\beta$ cells
}

\author{
Wei-na Ma*, Shin-Young Park* and \\ Joong-Soo Han ${ }^{1}$
}

Department of Biochemistry and Molecular Biology

College of Medicine, Hanyang University

Seoul 133-791, Korea

${ }^{1}$ Corresponding author: Tel, 82-2-2220-0623;

Fax, 82-2-2294-6270; E-mail, jshan@ hanyang.ac.kr

*These authors contributed equally to this work.

DOI 10.3858/emm.2010.42.6.047

Accepted 6 May 2010

Available Online 6 May 2010

Abbreviations: BFA, Brefeldin A; mTOR, mammalian target of rapamycin; p70S6K, p70 ribosomal S6 kinase

\begin{abstract}
As glucose is known to induce insulin secretion in pancreatic $\beta$ cells, this study investigated the role of a phospholipase $D$ (PLD)-related signaling pathway in insulin secretion caused by high glucose in the pancreatic $\beta$-cell line MIN6N8. It was found that the PLD activity and PLD1 expression were both increased by high glucose $(33.3 \mathrm{mM})$ treatment. The dominant negative PLD1 inhibited glucose-induced Beta2 expression, and glucose-induced insulin secretion was blocked by treatment with 1-butanol or PLD1-siRNA. These results suggest that high glucose increased insulin secretion through a PLD1-related pathway. High glucose induced the binding of Arf6 to PLD1. Pretreatment with brefeldin A (BFA), an Arf inhibitor, decreased the PLD activity as well as the insulin secretion. Furthermore, BFA blocked the glucose-induced $m$ TOR and p70S6K activation, while $\mathrm{mTOR}$ inhibition with rapamycin attenuated the glucose induced Beta2 expression and insulin secretion. Thus, when taken together, PLD1 would appear to be an important regulator of glucose-induced insulin secretion through an Arf6/PLD1/mTOR/p70S6K/ Beta2 pathway in MIN6N8 cells.
\end{abstract}

Keywords: ADP-ribosylation factor 6; insulin; insulin-secreting cells; mTOR protein; phospholipase D1

\section{Introduction}

Glucose is the most potent nutrient in insulin secretion in pancreatic $\beta$-cells (Ashcroft, 1980; Goren, 2005). MIN6N8 cells are a type of mouse pancreatic $\beta$-cell line derived from transgenic mice expressing SV40 T transformed insulinoma cells under the control of an insulin promoter (Kim et al., 2005), which means they can secrete insulin in a regulated manner in response to varying concentrations of glucose.

The ubiquitously expressed enzyme phospholipase $D(P L D)$ catalyzes the formation of phosphatidic acid (PA) from the major membrane phospholipid phosphatidylcholine (Voss et al., 1999; Hughes et al., 2004). There is also growing evidence that PLD1 is essential for the regulated secretion of insulin from pancreatic $\beta$-cells (Metz and Dunlop, 1990) and modulates vesicular trafficking and exocytosis (Shen et al., 2001). Many factors have already been implicated in the regulation of PLD and insulin secretion in response to glucose such as GTPases proteins. Arfs are small G-proteins of the Ras superfamily and have been shown to have some effect on vesicle transport, endocytosis, actin rearrangement and insulin secretion (Jalink et al., 1994; Donaldson, 2003). Moreover, recent studies suggested that Arf6 is located at the plasma membrane and stimulates the activity of PLD (Luo et al., 1998; Liu et al., 2005). Nonetheless, the mechanisms of glucose-induced PLD activation mediating insulin secretion in pancreatic- $\beta$ cells are not yet well defined.

Insulin secretion is regulated by glucose at the transcriptional and post-transcriptional levels (Andrali et al., 2008). One transcriptional factor is Beta2. Which belongs to the bHLH (basic helix-loop-helix) family and functions in a complex with the ubiquitously expressed E47 protein (Naya et al., 1995). In MIN6 cells without glucose stimulation, Beta2 has been shown to be mainly localized in the cytosol, whereas exposure to high glucose causes its translocation into the nucleus, thereby inducing insulin secretion (Petersen et al., 2002). Therefore, this study attempted to elucidate whether PLD1 is involved in glucose-induced Beta2 expression. Recent studies have also found that PLD is an upstream regulator of mTOR signaling (Fang et al., 2003; Sun et al., 2008). mTOR (mammalian target of rapamycin) is a serine/threonine protein 
A

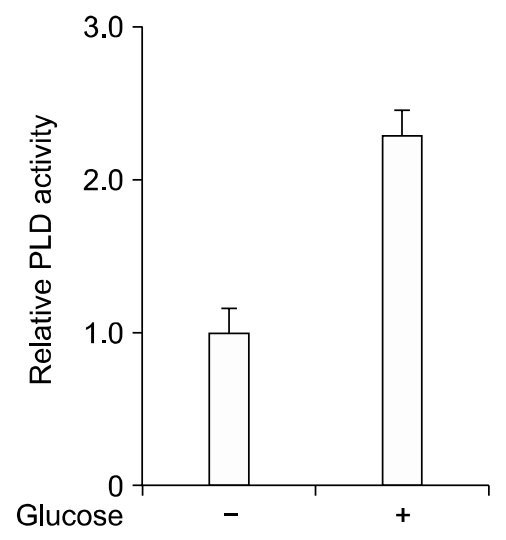

B

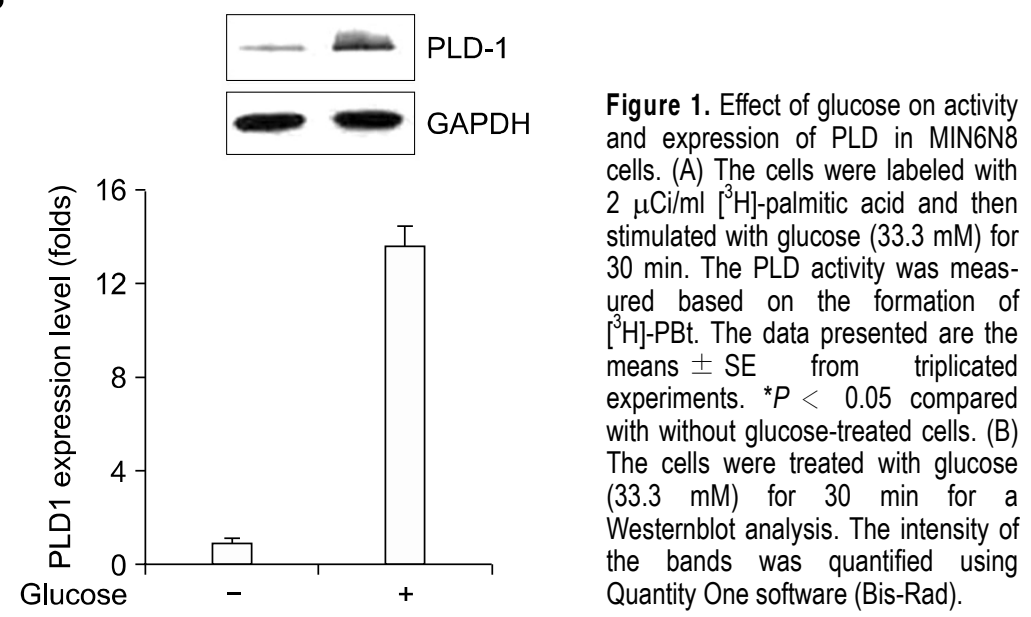

kinase that is vital for the regulation of cell growth in response to hormones and growth factors in all eukaryotic cells (Rohde et al., 2001; Crespo and Hall, 2002). mTOR promotes protein synthesis via two downstream effectors, 4E-BP1 (eukaryotic initiation factor 4E-binding protein-1) and p70S6K (p70 ribosomal S6 Kinase). Plus, the activation of mTOR has been reported as an essential step for the glucose uptake mechanism stimulated by insulin via a PI3K-Akt pathway (Cui et al., 2003; Vander Haar et al., 2007; Flati et al., 2008). However, the role of mTOR in insulin secretion from pancreatic $\beta$-cells stimulated by glucose is not yet fully understood.

Accordingly, the present study was conducted to find out whether PLD1 is involved in insulin secretion induced by glucose and what kinds of intracellular signals are related to PLD1 in pancreatic $\beta$-cells.

\section{Results}

\section{Effect of glucose on activity and expression of PLD in MIN6N8 cells}

First, to assess the role of PLD in the MIN6N8 cells, any change of PLD activity was checked in the presence of $33.3 \mathrm{mM}$ high glucose. As shown in Figure 1A, the PLD activity was significantly increased nearly 2.3 -fold in $30 \mathrm{~min}$. Thereafter, to analyze whether this increased PLD activity was due to the increased expression of PLD, the PLD expression was quantitated using a western blot analysis. The PLD1 expression was markedly increased during the glucose stimulation for $30 \mathrm{~min}$ (Figure 1B), yet no PLD2 was detected, even after glucose stimulation (data not shown), demonstrating that high glucose up-regulated the PLD activity and PLD1 protein expression.

\section{Effect of PLD1 on Beta2 gene expression and insulin secretion in glucose-stimulated MIN6N8 cells}

Earlier studies have shown that Beta2 regulates insulin exocytosis (Ishizuka et al., 2007) and is required for the regulation of insulin gene transcription (Mutoh et al., 1997; Sharma et al., 1999; Qiu et al., 2002). As shown by the RT-PCR analysis in Figure $2 \mathrm{~A}$, the Beta2 expression increased for $24 \mathrm{~h}$. To further test the potential role of PLD in Beta2 expression, MIN6N8 cells were transfected with wild types or catalytically inactive mutants of PLD1 plasmid constructs. Two days after the transfection, cells were treated with high glucose for $24 \mathrm{~h}$. As a result, PLD1 overexpression potentiated Beta2 expression increased by high glucose, whereas knockdown of PLD1 using DN-PLD1 transfection completely eliminated Beta2 expression (Figure 2B), strongly suggesting that PLD1 was involved in the Beta2 expression induced by glucose in the MIN6N8 cells. The next issue was to establish whether PLD activity was required for insulin secretion. Pretreatment of cells with 1-butanol, which inhibits PA production by PLD, significantly decreased glucose-induced insulin secretion. In contrast, 2-butanol, which can not be transphosphatidylated, did not show any effect on insulin secretion (Figure 2C). In addition, the depletion of PLD1 by PLD1siRNA significantly decreased insulin secretion in glucose-stimulated MIN6N8 cells (Figure 2D). Thus, when taken together, these results indicated that PLD1 acted as an important mediator for Beta2 expression and insulin secretion in the MIN6N8 cells stimulated by glucose. 
A

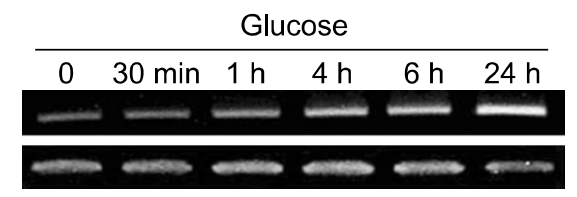

Beta2

$\beta$-actin

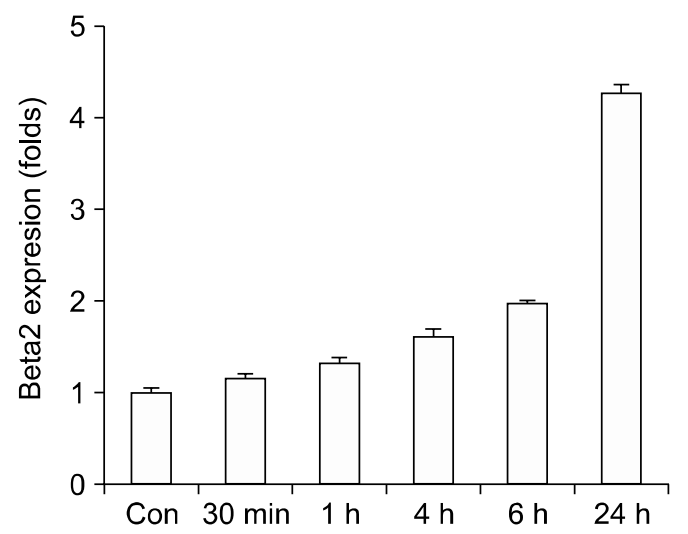

C

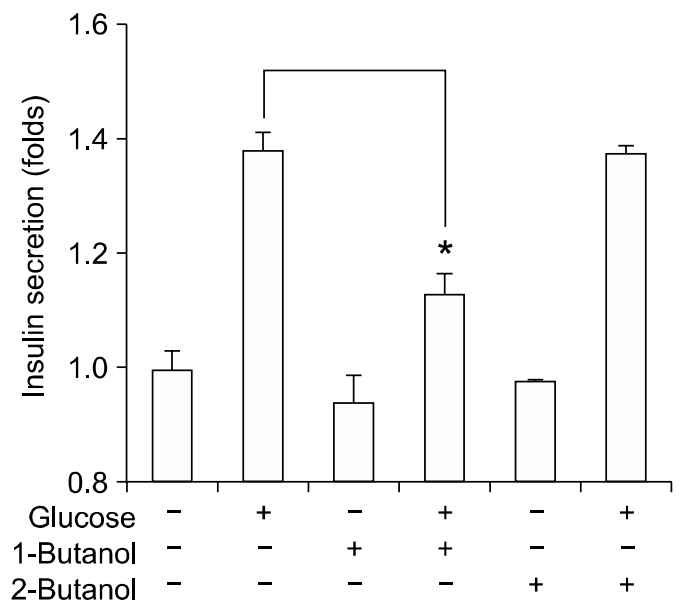

B
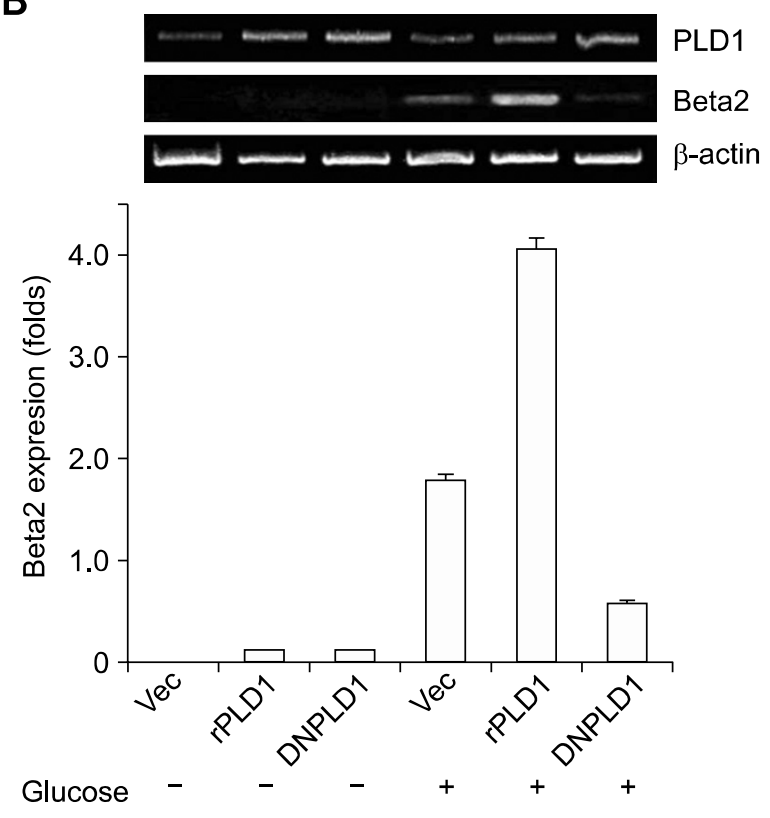

D
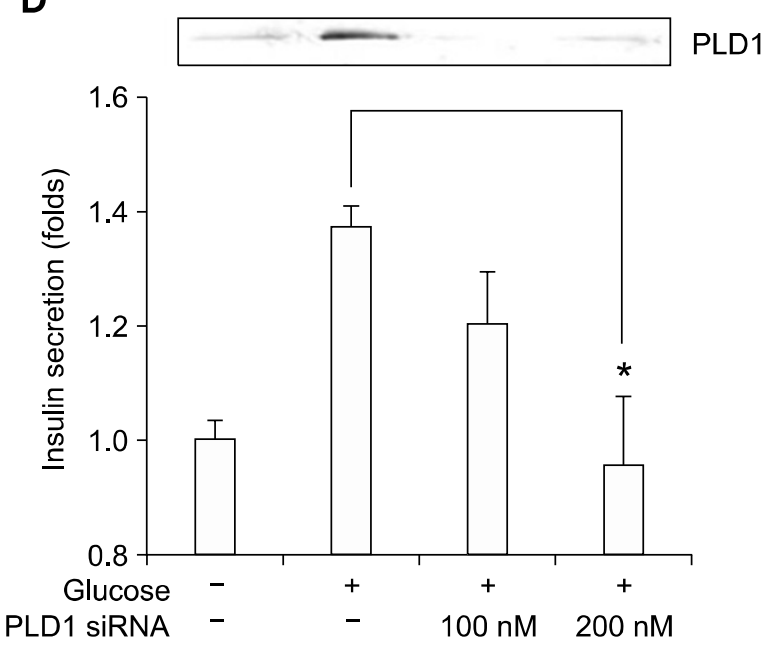

Figure 2. Effect of PLD1 on Beta2 gene expression and insulin secretion in glucose-stimulated MIN6N8 cells. (A) The cells were treated with glucose for the indicated times for an RT-PCR. (B) The cells were transfected with $5 \mu \mathrm{g}$ of either EGFP, EFFP-rPLD1,or EGFP-DNPLD1 for $6 \mathrm{~h}$, then treated with glucose for $24 \mathrm{~h}$, and the mRNA levels of PLD1 and beta2 determined using an RT-PCR. (C) The insulin secretion was measured based on the RIA of the cell supernatants (see "Methods"). At the end of the incubation, replaced with fresh KRB buffer and the cells incubated for 30 min with 1- or 2-butanol before being stimulated with glucose for $24 \mathrm{~h}$. (D) As in C, the cells were transfected with PLD1siRNA for $48 \mathrm{~h}$ and then stimulated with glucose for $24 \mathrm{~h}$. Values are shown are means \pm S.E. from three independent experiments. The significance of each difference is indicated as a $P$ value. ${ }^{*} P<0.05$ compared with glucose-treated cells.

\section{Arf6 is involved in glucose-induced insulin secretion pathway}

Previous work has shown that Arf6 is involved in altering the membrane phospholipid composition by stimulating PLD activity, in vitro (Caumont et al., 1998). Hence, to determine the relationship between Arf6 and PLD1, double immunostaining techniques were used in the MIN6N8cells. As shown in Figure 3A, in unstimulated cells, Arf6 was localized in the cytosol. However, upon glucose stimulation, Arf6 was redistributed from cytosol to membrane, and merged with PLD1. Meanwhile, the cells stained for both of Arf6 and PLD1 showed yellow fluorescent staining, indicating an increased membrane translocation of Arf6 and then co-localization with PLD1 when stimulated by high glucose. 
A
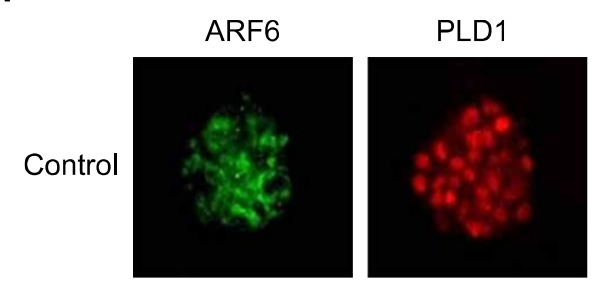

ARF6/PLD1

Glucose

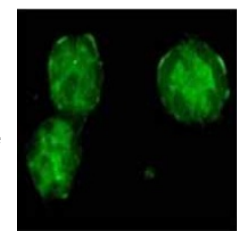

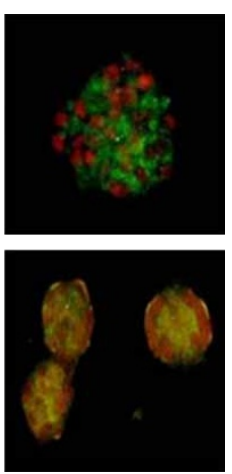

B

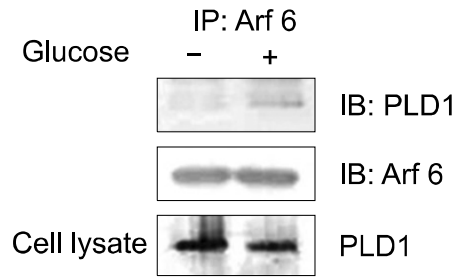

E

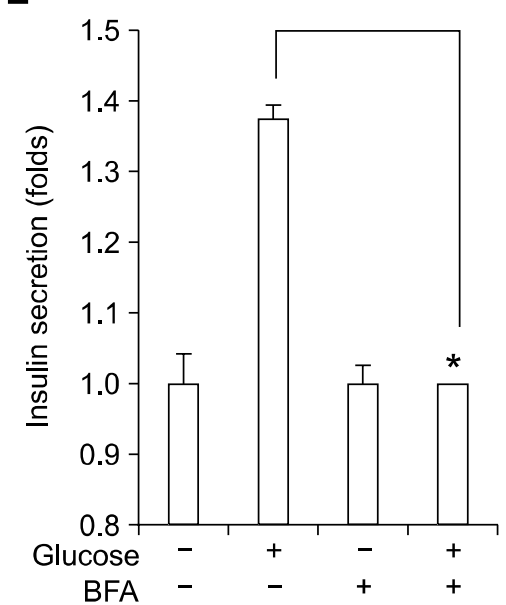

C

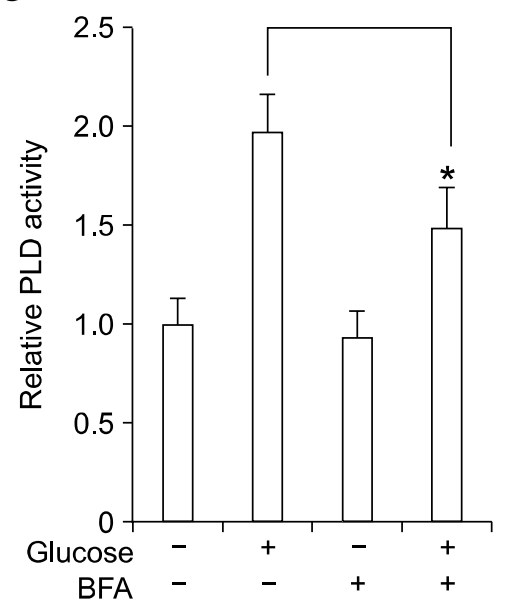

D

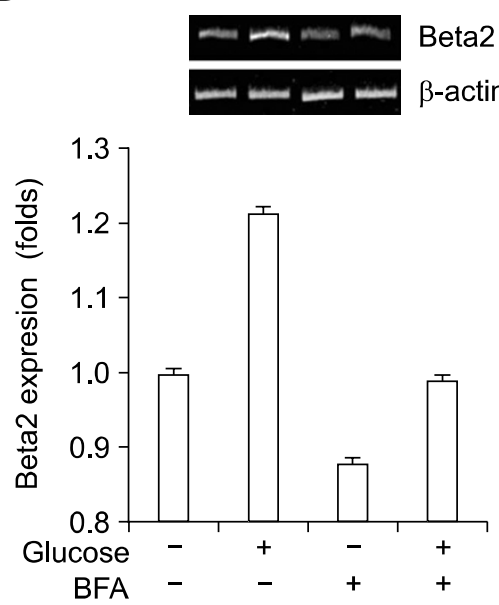

Figure 3. Involvement of Arf6 in glucose-induced insulin secretion pathway. (A) The MIN6N8 cells were transfected with the EGFP-PLD1 plasmid for $48 \mathrm{~h}$, stimulated by glucose for $30 \mathrm{~min}$, and then fixed and labeled for Arf6 and GFP. Arf6 is shown in green, PLD1 is shown in red and the final merged images are yellow. (B) The cells were transfected with the PLD1 plasmid for $24 \mathrm{~h}$, shifted to a medium containing glucose for 30 min, lysates prepared and subjected to immunoprecipitation with the anti-Arf6 antibody overnight, and the Arf6 immunoprecipitate (IP: Arf6) then subjected to a Westernblot analysis. (C) The cells were labeled with $2 \mu \mathrm{Ci} / \mathrm{ml}\left[{ }^{3} \mathrm{H}\right]$-palmitic acid and then treated for $30 \mathrm{~min}$ with or without $10 \mu \mathrm{M} \mathrm{BFA}$ and then for 30 min with or without glucose, as indicated. The PLD activity was measured based on the formation of $\left[{ }^{3} \mathrm{H}\right]-\mathrm{PBt}$. (D) The RNA was extracted from cells pretreated with $10 \mu \mathrm{M}$ BFA for 30 min, then stimulated with glucose for $24 \mathrm{~h}$ for an RT-PCR. (E) The cells were incubated for 30 min with BFA before stimulation with glucose for $24 \mathrm{~h}$ for an RIA assay. Values are shown are means \pm S.E. from three independent experiments. The significance of each difference is indicated as a $P$ value. ${ }^{*} P$ $<0.05$ compared with the glucose-treated cells.

To confirm this result, an immunoprecipitation study of Arf6 and PLD1 was performed. As seen in Figure $3 \mathrm{~B}$, a robust interaction was observed between Arf6 and PLD1 after treatment with glucose. In contrast, there was no interaction between Arf6 and PLD1 without glucose treatment, indicating that Arf6 binds to PLD1 under high glucose conditions in MIN6N8 cells. Thus, given the association of Arf6 with PLD1, the ability of Arf6 to regulate PLD activity in MIN6N8 cells was also investigated. As shown in Figure 3C, PLD activity was significantly decreased by treatment of Brefeldin A (BFA), which is a fungal metabolite that blocks Arf activation by accelerating guanine nucleotide exchange. Therefore, these results supported that Arf6 co-localization with PLD1 increased PLD activity under high glucose condition in MIN6N8 cells. To further elucidate the role of Arf6 in glucose stimulated insulin secretion, the effects of BFA on glucose-induced Beta2 expression and insulin secretion were investigated. MIN6N8 cells were pretreated with or without BFA for $30 \mathrm{~min}$, and then incubated in the presence or absence of $33.3 \mathrm{mM}$ glucose for $24 \mathrm{~h}$. As shown in Figures 3D and 3E, glucose-induced Beta2 expression was blocked by BFA treatment, while 
A

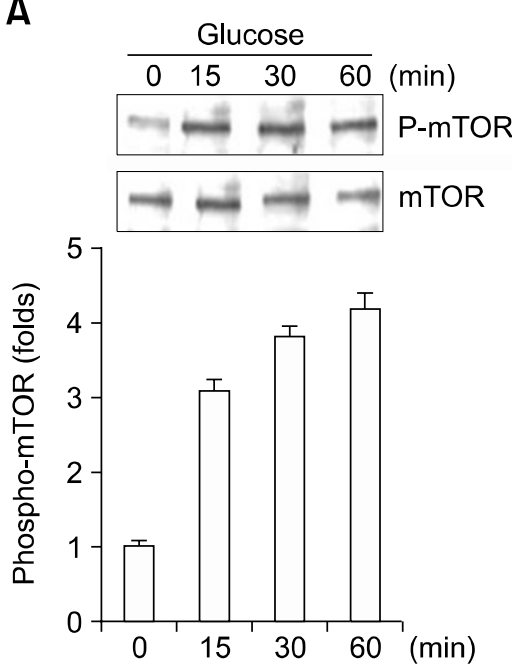

D

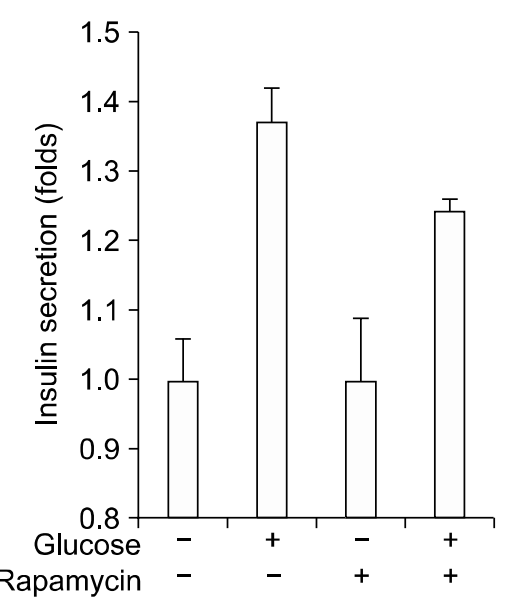

B

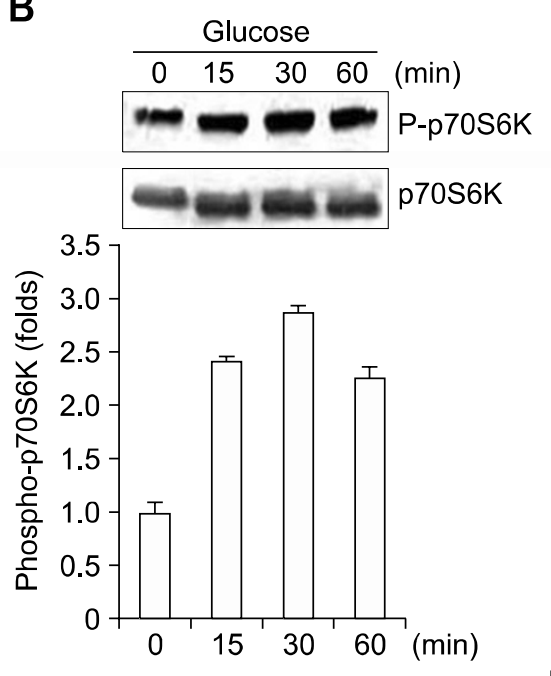

C

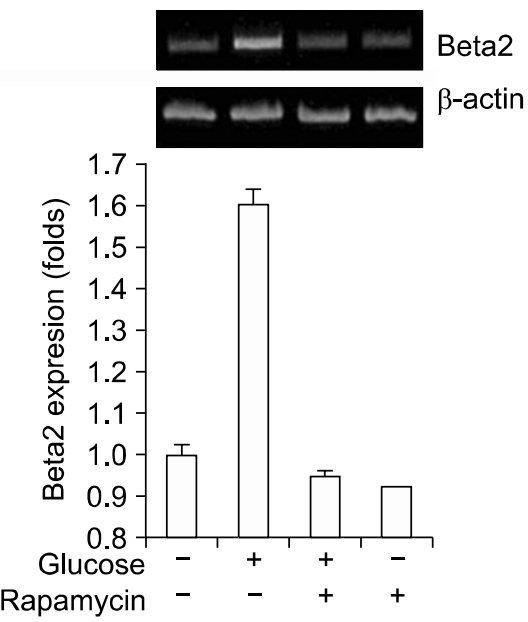

E

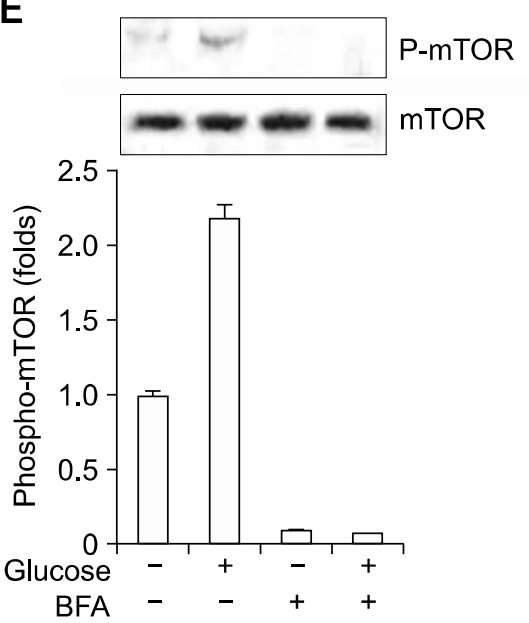

$F$

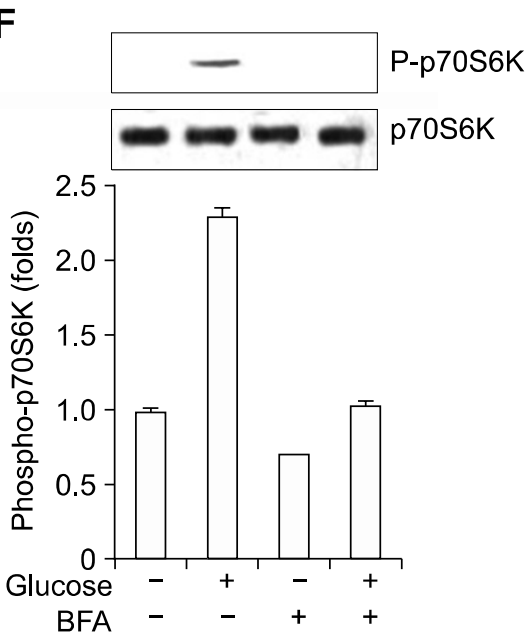

Figure 4. Involvement of mTOR and p70S6K in insulin secretion induced by glucose in MIN6N8 cells. (A and B) The cells were stimulated with glucose for the indicated time, then processed for immunoblotting. (C) The cells were pretreated with $300 \mathrm{nM}$ rapamycin for 30 min, stimulated with glucose for 24 $\mathrm{h}$, and the total RNA isolated using the Trizol reagent for an RT-PCR. (D) The cells were incubated for 30 min with rapamycin before stimulation with glucose for $24 \mathrm{~h}$ for an RIA assay. ( $\mathrm{E}$ and F) The cells were pretreated with $10 \mu \mathrm{M}$ BFA for 30 min and then stimulated with glucose for 30 min. The Western blot analysis was carried out as described in the Methods.

glucose-induced insulin secretion was completely decreased to the control levels. Thus, when taken together, the evidence strongly indicated that Arf6 was a major contributor to the insulin secretion pathways induced by glucose via PLD1 activation in MIN6N8 cells.

\section{Involvement of mTOR and p70S6K in insulin secretion induced by glucose in MIN6N8 Cells}

In MIN6 cells, one of the targets of glucose is p70S6K (Gomez et al., 2004; Gleason et al., 2007). However, the mechanisms of insulin secre- tion induced by glucose on mTOR activity via a PLD1 pathway have not yet been determined. Therefore, the phosphorylation pattern of mTOR and p70S6K after treatment with glucose was examined first. As shown in Figures $4 \mathrm{~A}$ and $4 \mathrm{~B}$, a time course analysis showed that glucose induced increased phosphorylation of mTOR and p70S6K, reaching a maximum after $30 \mathrm{~min}$. Next, it was investigated whether the mTOR/p70S6K pathway mediates glucose-induced insulin secretion. As seen in Figure 4C, when cells were preincubated with rapamycin, a specific inhibitor of mTOR, glucose induced Beta2 expression was significantly 
eliminated when compared to control. Consequently, insulin secretion was also impaired by rapamycin treatment (Figure 4D). Therefore, these results suggested that the $\mathrm{mTOR} / \mathrm{p} 70 \mathrm{~S} 6 \mathrm{~K}$ pathway was critical for glucose-induced insulin secretion in MIN6N8 cells

Next, the roles of Arf6 and PLD activity in the activation of mTOR and p70S6K were examined. The cells were pretreated with BFA to block Arf6 which activated PLD under high glucose condition. As expected, pretreatment of the cells with BFA markedly inhibited the phosphorylation of mTOR and p70S6K induced by glucose (Figures 4E and $4 \mathrm{~F})$. Thus, the results demonstrated that mTOR and p70S6K were both involved in glucose-induced insulin secretion through Arf6 activation leading to increased PLD activity in the MIN6N8 cells.

\section{Discussion}

Although previous studies have studied the function of PLD in pancreatic $\beta$-cells, they focused predominantly on PLD in exocytosis (Shen et al., 2001), especially how the enzyme works in insulin-stimulated glucose uptake pathways (Standaert et al., 1996; Shome et al., 1997; Emoto et al., 2000). Thus, to the best of our knowledge, this is the first time that PLD1 has been demonstrated to be an important regulator of insulin secretion through a glucose-stimulated Arf6/PLD1/mTOR/p70S6K pathway in MIN6N8 cells.

The present study showed that: First, the PLD activity as well as the expression level of the PLD1 protein were increased by glucose treatment of the cells (Figure 1), indicating that PLD1 may be a key regulator in glucose-regulated signaling pathways. Second, and most importantly, PLD1 accounted for Beta2 expression and insulin secretion. PLD1 overexpression synergistically increased Beta2 expression induced by glucose (Figure 2B). Conversely, transfection of PLD2 had no effect on Beta2 expression (data not shown). Therefore, it was clarified that PLD1, rather than PLD2, is a very important mediator in Beta2 expression induced by glucose, resulting in insulin secretion. Meanwhile, the down-regulation of PLD activity using 1-butanol and PLD1siRNA inhibited the insulin secretion in response to glucose. As a result, PLD1was demonstrated to play an important role in glucose-stimulated insulin secretion in pancreatic $\beta$ cells. These data are also supported by Hughes et al. (2004) who showed that, PLD activity is required for insulin secretion in the pancreatic $\beta$ cell line MIN6. Third, Arf6 was found to bind and co-localize with PLD1 in glucose stimulated cells to activate PLD (Figure 3). Beta2 expression and insulin secretion were both blocked by BFA, suggesting the participation of Arf6 in a glucose-stimulated insulin secretion pathway in the MIN6N8 cells. Fourth, when the MIN6N8 cells were treated with rapamycin, the Beta2 expression and insulin secretion induced by glucose were both decreased. Furthermore, the inhibition of Arf with BFA significantly blocked the activation of mTOR and p70S6K (Figure 4), suggesting that mTOR and p70S6K are located downstream of PLD1 in the glucose-stimulated insulin secretion signaling pathways. The effect of glucose on 4E-BP1 phosphorylation was also examined, but there was no change in the expression of this protein (data not shown).

Multiple Arf forms play specific functions for different members of the family. Only Arf6 is located at the plasma membrane and plays a key role in receptor transduction mechanisms. Moreover, some findings have suggested that Arf6 contributes to PLD activation at the plasma membrane, after forming a complex with PLD1 and plays a role in the secretion of insulin in the pancreatic $\beta$ cell line MIN6 (Massenburg et al., 1994; Vitale et al., 2002). The present data strongly suggested a functional relationship between PLD1 and Arf6, which resulted in increasing the insulin secretion. The role of Arf in signal transduction raises some questions regarding the nature of the interactions between PLD1 and Arf6. Thus, it would be interesting to determine whether Arf6 interacts with PLD1 directly or via some unknown factors to regulate PLD activity. Nonetheless, it was found that Arf6 was able to bind and co-localize with PLD1, thereby, acting as a PLD activator.

Another issue addressed in this study was the

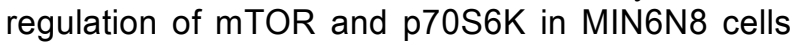
by glucose. In pancreatic $\beta$ cells, glucose enters the $\beta$-cells via the GLUT2 transporter, leading to a rise of ATP. This increase in the ATP levels then activates mTOR, which acts as an "ATP sensor" (Dennis et al., 2001; Briaud et al., 2003), resulting in the upregulation of glucose-induced mTOR and p70S6K phosphorylation. However, in the present study, the glucose-induced insulin secretion was not significantly decreased by rapamycin treatment, possibly because the insulin secretion stimulated by glucose is regulated at the transcriptional level. The transcription factors for glucose-regulated insulin gene expression include Beta-2, $\mathrm{Pdx}-1$, MafA and INS-1/2 (Roderigo-Milne, 2002; Andrali et al., 2008). Which operate in a co-ordinated and synergistic manner to activate insulin gene expression. In particularly, Beta-2, Pdx-1 and MafA are 


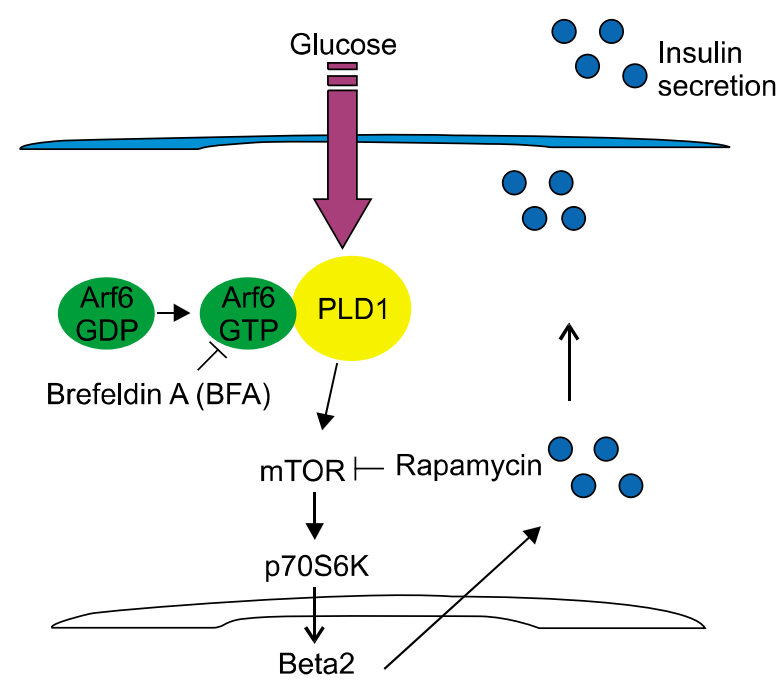

Figure 5. Potential linking of glucose-induced insulin secretion with increased PLD activity of in MIN6N8 cells. The proposed suggests that glucose induces beta2 expression and insulin secretion via the activation of PLD1 through Arf6/mTOR/p70S6k in MIN6N8 cells. Glucose increased the PLD1 activity in the MIN6N8 cells, probably through Arf6 activation. As such, the activated form of Arf6 binds to PLD1, which then lead to the activation of mTOR, resulting in increased insulin secretion through Beta2 upregulation.

co-expressed, and can strongly activate an insulin promoter (Aramata et al., 2005; Docherty et al., 2005). However, the study only focused on Beta2 expression under high glucose conditions, as only the Beta2 expression was decreased by rapamycin treatment. While the other transcription factors, such as Pdx-1 and INS-1/2, were unaffected (Data not shown). To confirm whether the mTOR/p70S6K pathway was related to Arf6, pretreatment with BFA was prior to glucose stimulation produced a decrease in the phosphorylation of $\mathrm{mTOR}$ and p70S6K. Therefore, it would appear that $\mathrm{mTOR} / \mathrm{p} 70 \mathrm{~S} 6 \mathrm{~K}$ pathway is located downstream of Arf6 for glucose-induced insulin secretion in MIN6N8 cells.

Thus, when taken together, the present results indicate that PLD1 is an important intermediate in the glucose-stimulated insulin secretion system through an Arf6/PLD1/mTOR/ p70S-6K/Beta2 pathway in pancreatic $\beta$-cell, MIN6N8 (Figure 5).

\section{Methods}

\section{Cell culture}

The MIN6N8 cells were kindly provided by Dr. M.S. Lee (Sungkyunkwan University School of Medicine, Seoul, Korea) and were incubated at $37^{\circ} \mathrm{C}$ with $5 \% \mathrm{CO}_{2}$ in DMEM containing 15\% fetal bovine serum, $2 \mathrm{mmol} / \mathrm{l}$ glutamine, 100 $\mathrm{IU} / \mathrm{ml}$ penicillin, and $100 \mu \mathrm{g} / \mathrm{ml}$ streptomycin (Lonza, MD).

\section{Reagents}

BFA was obtained from Calbiochem (CA). Glucose and rapamycin were from Sigma-Aldrich (MO). mTOR polyclonal antibody and p-mTOR polyclonal antibody, p70S6K polyclonal antibody and p-70S6K polyclonal antibody were all purchased from Cell Signaling (MA); GAPDH polyclonal antibody was obtained from Santa Cruz Biotechnology (CA). The PLD1 polyclonal antibody was provided by Dr. D. S. Min (Pusan National University, Korea), L- $\alpha$-phosphatidylbutanol (PBt) was from Avanti Polar Lipids (AL), and the silica gel 60A plates for TLC were purchased from Whatman (NJ).

\section{Immunoprecipitation and immunoblot analysis}

Harvested MIN6N8 cells were lysised in $20 \mathrm{mM}$ HEPES $(\mathrm{pH} 7.2), 200 \mathrm{mM}$ sodium chloride, $1 \%$ Triton $\mathrm{X}-100,2 \%$ cholic acid, $1 \mathrm{mM}$ EDTA, $1 \mathrm{mM}$ EGTA, $0.1 \mathrm{mM}$ DTT, 10 $\mathrm{mg} / \mathrm{ml}$ leupeptin, $10 \mathrm{mg} / \mathrm{ml}$ aprotinine and $1 \mathrm{mM}$ PMSF on ice and disrupted by sonication. After $2 \mathrm{~h}$ of incubation in an ice bath, $40 \mathrm{ml}$ of protein $\mathrm{G}$ sepharose was added. The immune complexes were then recovered by centrifugation at $2,000 \times g$ for $5 \mathrm{~min}$ at $4^{\circ} \mathrm{C}$. For the immunoblot analysis, the immunoprecipitates were washed five times in a washing-buffer (50 mM Tris- $\mathrm{HCl}(\mathrm{pH} \mathrm{8.0),} \mathrm{1 \%} \mathrm{Triton} \mathrm{X-100,}$ $1 \%$ sodium deoxycholate, $0.1 \%$ sodium dodecylsulfate and $200 \mathrm{mM}$ sodium chloride). For the gel electrophoresis, the immune complexes were dissolved in a $2 \times$ Laemmli cooking buffer, separated using an SDS-polyacrylamide gel, and transferred onto nitrocellulose membranes. The immunoreactive bands were then visualized using peroxidase conjugated secondary antibodies and specific bands detected by ECL (Amersham Phamacia Biotech, $\mathrm{NJ})$.

\section{RNA extraction and real-time PCR}

Total RNA was extracted from MIN6N8cells using the TRIzol reagent (Life Technologies Inc., MD). Next, $5 \mu \mathrm{g}$ of total RNA was mixed with oligo (dT)16 primer and Maloney murine leukemia virus (M-MLV) reverse transcriptase (Promega, WI), and incubated for $60 \mathrm{~min}$ at $42^{\circ} \mathrm{C}$. The transcribed products were mixed with each primer set and Taq DNA polymerase (Takara Shuzo, Japan), and then amplified. The primer sequences were as follows: Beta2 sense (5'-CTTGGCCAAGAACTACATCTGG-3') and antisense (5'-GGAGTAGGGAT-GCACCGGGAA-3') (PCR product, $225 \mathrm{bp}$ ); mouse $\beta$-actin sense (5'-ATCCTGAAAGACCTCTATGC-3') and antisense (5'-AACGCAGCTCAGTAACAGTC-3') (PCR product, $287 \mathrm{bp}$ ). The PCR products were analyzed in $1.2 \%$ agarose-gel.

\section{Determination of PLD activity}

PLD activity was determined by measuring the $\left[{ }^{3} \mathrm{H}\right]-\mathrm{PBt}$ produced via PLD catalyzed transphosphatidylation in $\left[{ }^{3} \mathrm{H}\right]$-palmitic acid labeled cells (Lim et al., 2002). MIN6N8 cells were radioactively labeled overnight with $2 \mu \mathrm{Ci} / \mathrm{ml}$ of $\left[{ }^{3} \mathrm{H}\right]$ palmitic acid in medium, and then pretreated with $0.3 \%(\mathrm{v} / \mathrm{v})$ 1-butanol for $15 \mathrm{~min}$ before stimulation with glucose. The cells were incubated with BFA, rapamycin for 
$30 \mathrm{~min}$, after treatment with glucose for $30 \mathrm{~min}$, and then quickly washed with PBS and suspended in ice-cold methanol. Lipids were extracted according to the method of Bligh and Dyer (Bligh and Dyer, 1959), and PBt was separated by TLC using an acetate/isooctane/acetic acid/water (110:50:20:100,v/v) solvent system. The regions corresponding to authentic PBt bands $(\mathrm{Rf}=0.76)$ were identified with $0.002 \%(\mathrm{w} / \mathrm{v})$ primulin in $80 \%(\mathrm{v} / \mathrm{v})$ acetone, scraped, and counted using a liquid scintillation counter.

\section{Small interfering RNA}

siRNA was used to knock-down the targeted genes, and the PLD1 siRNA oligonucleotide (5'-AAGGUGGGACGACAAUGAGCA-3') was synthesized by Ambion (TX). MIN6-N8 cells were transfected using the siPORT $^{\text {TM }}$ NeoFX (Ambion, TX) reagent according to the manufacturer's instructions, and the cell lysates were assayed for insulin secretion.

\section{Immunocytochemistry}

MIN6N8 cells were plated on coverslips in 24 well plates. The cells were fixed with $4 \%(\mathrm{w} / \mathrm{v})$ paraformaldehyde $/ 0.15 \%(\mathrm{w} / \mathrm{v})$ picric acid in phosphate-buffered saline, and then incubated overnight with primary antibody at $4{ }^{\circ} \mathrm{C}$. The Green Fluorescent Protein (GFP) monoclonal antibody was used at 1:400 (Roche Molecular Biochemicals, Basel, Switzerland), Arf6 antibody was used at 1:400 (Santa Cruz Biotechnology, CA), then with a secondary antibody (Cy3) (Jackson ImmunoResearch Laboratories, PA). Cells were mounted using the VECTASHIELD (Vector laboratories, $\mathrm{CA})$ mounting medium for fluorescence and photographed using a fluorescent microscope (Nikon, Japan).

\section{Insulin secretion assay}

MIN6N8 cells grown in 24-well plates were washed in a Krebs-Ringer bicarbonate (KRB) buffer containing $5 \mathrm{mM}$ $\mathrm{NaHCO}_{3}, 10 \mathrm{mM}$ HEPES, pH7.4, $1 \mathrm{mM} \mathrm{CaCl}, 0.5 \%$ (w/v) bovine serum albumin, then incubated for an additional $4 \mathrm{~h}$ in $0.5 \mathrm{ml}$ of the KRB buffer. After discarding the buffer, the cells were treated with the inhibitors used in this experiments for $30 \mathrm{~min}$, and then treated with high glucose $(33.3 \mathrm{mM})$ for $24 \mathrm{~h}$. The supernatants were collected and frozen for insulin assays. Thereafter, cells were washed with PBS and extracted with $0.18 \mathrm{~N} \mathrm{HCl}$ in $70 \%$ ethanol for $24 \mathrm{~h}$ at $4^{\circ} \mathrm{C}$. The acid-ethanol extracts were collected to determine the intracellular insulin content, which was measured based on radioimmunoassay using mouse insulin as the standard (Kim et al., 2005).

\section{Statistical analysis}

All the experiments were performed at least three to five times. The data shown in the figures are mean \pm S.E. Statistical significance was calculated using a one-way ANOVA analysis.

\section{Acknowledgments}

This work was supported by Medical Research Center
(2009-091462) programs, Ministry of Science and Technology, Republic of Korean, and partly supported by a grant from the Korean Healthcare Technology R\&D Project, Ministry for Health, Welfare \& Family Affairs, Republic of Korea (A084985).

\section{References}

Andrali SS, Sampley ML, Vanderford NL, Ozcan S. Glucose regulation of insulin gene expression in pancreatic $\beta$-cells. Biochem J 2008;415:1-10

Aramata S, Han SI, Yasuda K, Kataoka K. Synergistic activation of the insulin gene promoter by the beta-cell enriched transcription factors MafA, Beta2, and Pdx1. Biochim Biophy Acta 2005;1730:41-6

Ashcroft SJ. Glucoreceptor mechanisms and the control of insulin release and biosynthesis. Diabetologia 1980;18:5-15

Bligh EG, Dyer WJ. A rapid method of total lipid extraction and purification. Can J Biochem Physiol 1959;37:911-7

Briaud I, Lingohr MK, Dickson LM, Wrede CE, Rhodes CJ. Differential activation mechanisms of Erk-1/2 and p70S6K by glucose in pancreatic $\beta$-cells. Diabetes 2003;52:974-83

Caumont AS, Galas MC, Vitale N, Aunis D, Bader MF. Regulated exocytosis in chromaffin cells. Translocation of ARF6 stimulates a plasma membrane-associated phospholipase D. J Biol Chem 1998;273:1373-9

Crespo JL, Hall MN. Elucidating TOR signaling and rapamycin action: lessons from Saccharomyces cerevisiae. Microbiol Mol Biol Rev 2002;66:579-91

Cui X, Zhang P, Deng W, Oesterreich S, Lu Y, Mills GB, Lee AV. Insulin-like growth factor-I inhibits progesterone receptor expression in breast cancer cells via the phosphatidylinositol 3-Kinase/Akt/Mammalian target of rapamycin pathway: progesterone receptor as a potential Indicator of growth factor activity in breast cancer. Mol Endocrinol 2003;17: 575-88

Dennis PB, Jaeschke A, Saitoh M, Fowler B, Kozma SC, Thomas G. Mammalian TOR: a homeostatic ATP sensor. Science 2001;294:1102-5

Docherty HM, Hay CW, Ferguson LA, Barrow J, Durward E, Docherty K. Relative contribution of PDX-1, MafA and E47/Beta2 to the regulation of the human insulin promoter. Biochem J 2005; 389:813-20

Donaldson JG. Multiple roles for Arf6: sorting, structuring and signaling at the plasma Membrane. J Biol Chem 2003;278: 41573-6

Emoto M, Klarlund JK, Waters SB, Hu V, Buxton JM, Chawla A, Czech MP. A role for phospholipase D in GLUT4 glucose transporter translocation. J Biol Chem 2000;275:7144-51

Fang Y, Park IH, Wu AL, Du G, Huang P, Frohman MA, Walker SJ, Brown HA, Chen J. PLD1 regulates mTOR signaling and mediates Cdc42 activation of S6K1. Curr Biol 2003;13: 2037-44

Flati V, Pasini E, D'Antona G, Speca S, Toniato E, Martinotti $S$. Intracellular mechanisms of metabolism regulation: the 
role of signaling via the mammalian target of rapamycin pathway and other routes. Am J Cardiol 2008;101:16E-21E

Gleason CE, Lu D, Witters LA, Newgard CB, Birnbaum MJ. The role of AMPK and $\mathrm{mTOR}$ in nutrient sensing in pancreatic beta-cells. J Biol Chem 2007;282:10341-51

Gomez E, Powell ML, Greenman IC, Herbert TP. Glucosestimulated protein synthesis in pancreatic $\beta$-cells parallels an increase in the availability of the translational ternary complex (elF2-GTP.Met-tRNAi) and the dephosphorylation of elF2 $\alpha$. J Biol Chem 2004;279:53937-46

Goren HJ. Role of insulin in glucose-stimulated insulin secretion in Beta cells. Curr Diabetes Rev 2005;1:309-30

Hughes WE, Elgundi Z, Huang P, Frohman MA, Biden TJ. Phospholipase D1 relates secretagogue-stimulated insulin release in pancreatic $\beta$-cells. J Biol Chem 2004;279: 27534-41

Ishizuka N, Minami K, Okumachi A, Okuno M, Seino S. Induction by NeuroD of the components required for regulated exocytosis. Biochem Biophys Res Commun 2007;354:271-7

Jalink K, J van Corven E, Hengeveld T, Morii N, Narumiya S, Moolenaar $\mathrm{WH}$. Inhibition of lysophosphatidate-and thrombin-induced neurite retraction and neuronal cell rounding by ADP ribosylation of the small GTP-binding protein Rho. J Cell Biol 1994;126:801-10

Kim WH, Lee JW, Suh YH, Hong SH, Choi JS, Lim JH, Song $\mathrm{JH}$, Gao B, Jung $\mathrm{MH}$. Exposure to chronic high glucose induces $\beta$-Cell apoptosis through decreased interaction of glucokinase with mitochondria downregulation of glucokinase in pancreatic $\beta$-Cells. Diabetes 2005;54:2602-11

Lim SY, Lee SC, Shin IC, Han JS. Differential effects of Fas cross-linking on phospholipase $D$ activation and related lipid metabolism in Fas-resistant A20 cells. Exp Mol Med 2002; 34:201-10

Liu L, Liao H, Castle A, Zhang J, Casanova J, Szabo G, Castle D. SCAMP2 interacts with Arf6 and phospholipase D1 and links their function to exocytotic fusion pore formation in PC12 Cells. Mol Biol Cell 2005;16:4463-72

Luo JQ, Liu X, Frankel P, Rotunda T, Ramos M, Flom J, Jiang $H$, Feig LA, Morris AJ, Kahn RA, Foster DA. Function association between Arf and RalA in active phospholipase D complex. Proc Natl Acad Sci USA 1998;95:3632-7

Massenburg D, Han JS, Liyanage M, Patton WA, Rhee SG, Moss J, Vaughan M. Activation of rat brain phospholipase D by ADP-ribosylation factors 1,5 , and 6: separation of ADP-ribosy-lation factor-dependent and oleate-dependent enzymes. Proc Natl Acad Sci USA 1994;91:11718-22

Metz SA, Dunlop M. Stimulation of insulin release by phospholipase D. A potential role for endogenous phosphatidic acid in pancreatic islet function. Biochem J 1990;270: 427-35

Mutoh H, Fung BP, Naya FJ, Tsai MJ, Nishitani J, Leiter AB.
The basic helix-loop-helix transcription factor BETA2/NeuroD is expressed in mammalian enteroendocrine cells and activates secretin gene expression. Proc Natl Acad Sci USA 1997:94:3560-4

Naya FJ, Stellrecht CM, Tsai MJ. Tissue-specific regulation of the insulin gene by a novel basic helix-loop-helix transcription factor. Genes Dev 1995;9:1009-19

Petersen HV, Jensen JN, Stein R, Serup P. Glucose induced MAPK signalling influences NeuroD1-mediated activation and nuclear localization. FEBS Lett 2002;528:241-5

Qiu Y, Guo M, Huang S, Stein R. Insulin gene transcription is mediated by interactions between the p300 coactivator and PDX-1, BETA2, and E47. Mol Cell Biol 2002;22:412-20

Roderigo-Milne $\mathrm{H}$, Hauge-Evans AC, Persaud SJ, Jones PM. Differential expression of insulin genes 1 and 2 in MIN6 cells and pseudoislets. Biochem Biophys Res Commun 2002;296:589-95

Rohde J, Heitman J, Cardenas ME. The TOR kinases link nutrient sensing to cell growth. J Biol Chem 2001;276:9583-6

Sharma A, Moore M, Marcora E, Lee JE, Qiu Y, Samaras S, Stein R. The NeuroD1/BETA2 sequences essential for insulin gene transcription colocalize with those necessary for neurogenesis and p300/CREB binding protein binding. Mol Cell Biol 1999;19:704-13

Shen $Y, X u$ L, Foster DA. Role for phospholipase D in receptor-mediated endocytosis. Mol Cell Boil 2001;21:595602

Shome K, Vasudevan C, Romero G. ARF proteins mediate insulin-dependent activation of phospholipase D. Curr Biol 1997; 7:387-96

Standaert ML, Bandyopadhyay G, Zhou X, Galloway L, Farese RV. Insulin stimulates phospholipase D-dependent phosphatidylcholine hydrolysis, Rho translocation, de novo phospholipid synthesis, and diacylglycerol/protein kinase C signaling in L6 myotubes. Endocrinology 1996;137:3014-20

Sun Y, Fang Y, Yoon MS. Phospholipase D1 is an effector of Rheb in the mTOR pathway. Proc Natl Acad Sci USA 2008; 105:8286-91

Vander Haar E, Lee SI, Bandhakavi S, Griffin TJ, Kim DH. Insulin signalling to mTOR mediated by the Akt/PKB substrate PRAS40. Nat Cell Biol 2007;9:16-23

Vitale N, Chasserot-Golaz S, Bailly Y, Morinaga N, Frohman A $M$, Marie-France B. Calcium-regulated exocytosis of dense-core vesicles requires the activation of ADP-ribosylation factor (ARF)6 by ARF nucleotide binding site opener at the plasma membrane. J Cell Biol 2002;159:79-89

Voss M, Weernink PA, Haupenthal S, Möller U, Cool RH, Bauer B, Camonis JH, Jakobs KH, Schmidt M. Phospholipase $D$ stimulation by receptor tyrosine kinases mediated by protein kinase $\mathrm{C}$ and a Ras/Ral signaling cascade. J Biol Chem 1999;274:34691-8 